\title{
Tackling Infrastructural Gap in Nigeria: The Pension Fund Option
}

\author{
Onwuka, Ifeanyi Onuka ${ }^{1} \&$ Nwafor, Michael ${ }^{1}$ \\ ${ }^{1} \mathrm{Ph} . \mathrm{D}$, Department of Accounting \& Finance, Godfrey Okoye University, Thinkers Corner, Enugu, Nigeria \\ Correspondence: Onwuka, Ifeanyi Onuka, Ph.D, ACIB, ACE, Department of Accounting \& Finance, Godfrey Okoye \\ University, Thinkers Corner, Enugu, Nigeria.
}

Received: October 16, 2017

Accepted: January 21, 2018 Available online: January 25, 2018

doi:10.11114/aef.v5i2.2952

URL: https://doi.org/10.11114/aef.v5i2.2952

\begin{abstract}
The paper reviewed the prospect of using the hugely untapped pension funds to bridge infrastructural financing gap in Nigeria. Infrastructure financing is estimated to cost Nigeria a total investment of USD2.9 trillion over the next 30 years to bring it to the level that can be competitive and self-sustaining. This huge investment outlay is clearly beyond the yearly fiscal operations of government. However, there is a glimmer of hope by way of pension funds, which as at August, 2016, is in excess of N5.9 trillion. This phenomenal growth in pension funds presents a rare opportunity to bridge the nation's current infrastructure gap by leveraging part of the huge pension assets for developmental purposes. The authors argued that there is need to review the regulatory and institutional framework in pension funds administration to make way for a creative use of some of the pension funds to fund infrastructure - creating a veritable profitable investment outlay for the pension funds contributors and at the same time providing the needed funding for critical infrastructure financing in the country.
\end{abstract}

Keywords: infrastructure, pension funds, infrastructural financing, infrastructural gap

\section{Introduction}

The Nigerian Integrated Infrastructure Master Plan (NIIMP, 2013) provides a capital allocation framework, which identifies the required investments to bring infrastructure ${ }^{1}$ in Nigeria in line with the country's growth aspirations. The plan also identifies and elaborates on enablers for implementation that would need to be put in place for successful execution.

Based on the economic growth aspirations, it is estimated that a total investment of USD2.9 trillion will be required over the next 30 years to build and maintain infrastructure in Nigeria. According to the NIIMP framework, Nigeria would need to increase investments in infrastructures in the preferred growth path, from the current USD10 billion per annum to USD15.9 billion per annum in 2014 and USD35 billion in 2018, averaging USD25 billion per annum (equivalent of 7\% of GDP) for the five-year period of 2014-2018. Thereafter, investment rate should further increase to $10 \%$ of GDP by 2014-2018 periods before stabilizing at 9\% of GDP for the rest of the 30-year plan until 2043 (NIIMP, 2013).

Based on sector growth strategies, outcome targets, and international benchmarks, the total investment of USD2900 billion over 2014-43 should comprise of investments in Energy - USD900billion, 32\% of total; Transport USD800billion, 28\% of total; Agriculture, Water and Mining - USD350billion, 12\% of total; ICT - USD 300billion, 11\% of total; Housing and Regional Development - USD300billion, 11\% of total; Social Infrastructure - USD150billion, 5\% of total; and Vital Registration and Security - USD50billion, 2\% of total. All these amounts were in constant 2010 prices (NIIMP, 2013).

It is expected that in the first year of the plan, investments in Energy, Transport, Social Infrastructure, and Housing and Regional Development should be given the largest attention due to their current relative level of underinvestment. It was also expected, according to the NIIMP (2013) framework that investments will grow over the next five years at an annual

\footnotetext{
${ }^{1}$ Infrastructure refers to the basic physical structures, systems and facilities responsible for the operational efficiency of a country or an organization. These include: railways, utilities, airports, highways, water, transport vehicles, telecommunication system, and bridges, among others. Soft infrastructures are software and programs providing functional framework for institutions, while hard infrastructure refers to tangible physical structures or facilities (NIIMP, 2013).
} 
growth rate of 39\% for Energy, 31\% for Transport, 32\% for Social Infrastructure, and 23\% for Housing and Regional Development. The remaining sectors would also need to grow investments, but at smaller growth rates of 6-12\% over the next five years. As a result, the investments required for the first five years of the plan were USD44billion in Energy, USD38billion in Transport; USD17billion in ICT; USD14billion in Water, Agriculture and Mining; USD7billion in Social Infrastructure; USD5billion in Housing and Regional Development; and USD2.5billion in the Vital Registration and Security, in constant 2013-value USD (NIIMP, 2013).

A cursory look at the NIIMP framework and projections shows that Nigeria has huge infrastructural gap which requires substantial investments in terms of financing and other resources to bridge. It is also clear that the government cannot provide the required funding from her annual fiscal operations. According to Nigerian Economic Summit Group (NESG) (2012), the Nigerian government must look beyond the traditional revenue sources (especially revenue from sale of crude oil) if the country must meet her growth aspirations in the provision of infrastructure. This is where the pension funds may come handy.

Since the introduction of Nigeria's pension contributory scheme in 2004, there has been an inverse relationship and a wide disconnect between the nation's stock of critical infrastructure and the pension funds. Nigeria's contributory pension fund hit an all-time high of N5.9trillion in September, 2016 as shown in Table 1 and 2

Table 1. Nigeria's Pension Assets (2010 - 2016)

\begin{tabular}{c|c}
\hline Year & Amount (N'Trillion) \\
\hline 2010 & 2.00 \\
\hline 2011 & 2.50 \\
\hline 2012 & 3.20 \\
\hline 2013 & 4.0 \\
\hline 2014 & 4.5 \\
\hline 2015 & 5.3 \\
\hline 2016 & 5.9 \\
\hline
\end{tabular}

Source: National Pension Commission (PenCom) (2016)

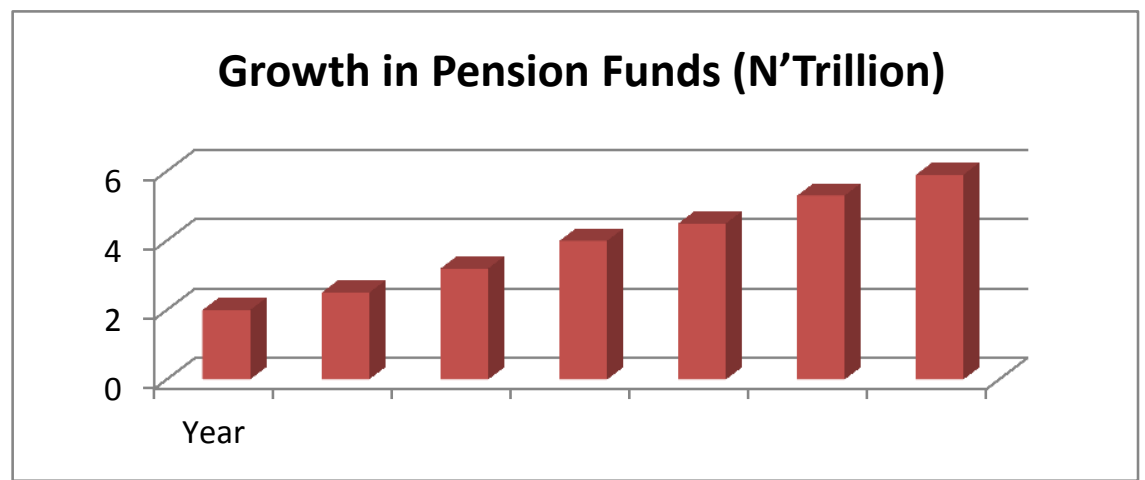

Table 2. Pension Assets Distribution As At September, 2016

\begin{tabular}{l|l|l}
\hline Class & Amount & Percentage \\
\hline Domestic Ordinary Shares & $1,338,284.62$ & 22.7 \\
\hline Foreign Ordinary Shares & $52,930.71$ & 1.28 \\
\hline Total FGN Securities & $3,638,414.69$ & 63.91 \\
\hline State Govt. Securities & $197,671.35$ & 4.79 \\
\hline Corporate Debt Securities & $80,457.96$ & 1.95 \\
\hline Supra-National Bonds & $1,730.35$ & 0.04 \\
\hline Local Money Market Securities & $318,080.63$ & 7.7 \\
\hline Foreign Money Market Securities & $1,015.42$ & 0.02 \\
\hline Open/Close-End Funds & $20,762.36$ & 0.5 \\
\hline Real Estate Property & $153,237.53$ & 3.71 \\
\hline Private Equity Fund & $51,406.08$ & 1.25 \\
\hline Cash \& Other Assets & $46,008.74$ & 1.11 \\
\hline Total Pension Fund Assets & $5,883,286.43$ & 100 \\
\hline
\end{tabular}

Source: Nigeria Pension Commission (PenCom) (2016)

As could be seen from Table 1, total pension assets in Nigeria stood at N5.128 trillion as at July 2016 accounting for about 6 percent of the country's gross domestic product (GDP). 
This growth in pension funds presents a rare opportunity to bridge the nation's current infrastructure gap by leveraging part of the huge pension assets for developmental purposes. According to Akinyosoye (2010), Nigeria's infrastructural financing need is likely to grow from the 2013 estimate of \$23billion to an estimated \$77billion by 2025.

The condition of Nigeria's core and social infrastructure is abysmal, requiring urgent attention by both government and the private sector. The country is currently facing its worst economic crisis in decades owing to a slump in crude oil prices, which account for over 70 percent of government revenue. And with the spill-over effects on other sectors of the economy as foreign exchange illiquidity cripple primary sectors such as aviation, manufacturing and services; policy responses from government have been chequered and inconsistent.

Nigeria has been unable to save sufficiently from oil windfalls - which peaked at $\$ 110$ per barrel in June 2014. And this is in spite of the fact that real GDP growth rate has averaged about 6.8 percent in the last decade (BGL Group (2016). Within the same period, and under successive governments, the country experienced low capital output ratio and poor maintenance of its infrastructure. This has exacerbated the current economic recession, with insufficient buffers to withstand shocks occasioned by low output and galloping inflation. Thus, it is imperative that the country adopts innovative approach towards bridging Nigeria's infrastructural gap. Perhaps, leveraging on pension funds to cut infrastructural deficits could be the game changer (Aremu, 2016).

The need to diversify from the traditional approach of financing infrastructure projects -public finance-and seek new sources and instruments of finance is now imperative. Perhaps, one veritable means of financing this infrastructure deficit is through the use of contributory pension funds estimated to be about N6trn (Six Trillion Naira). The Pension Reform Act ("the PFA") and the Regulation on Investment of Pension Fund Assets ("the Regulation") both regulate the investment of pension funds in infrastructure projects in Nigeria.

\subsection{Essence and Methodology}

The essence of this paper is to canvass support for the Federal Government of Nigeria (FGN) to leverage on the growing pension funds in the country to bridge the financing gap in infrastructural development. The methodology adopted is largely descriptive and analytical with anecdotal evidences to support the position of the paper.

The rest of the paper is divided into four sections. Following this introduction in section 1, section 2 focused on the Public-Private Partnership (PPP) model in infrastructure development. Section 3 dwelt on Pension Funds dynamics in Nigeria. Section 4 focused on leveraging pension funds for infrastructural development in Nigeria while section 5 concludes the paper with policy implication and recommendations

\section{Public-Private Partnership Initiative in Infrastructure Development}

Recently, private sector players have partnered with government to provide critical infrastructure. The Private-Public Partnership (PPP or P3s) ${ }^{2}$ has marginally helped to bridge the gap, although inclusive growth remains elusive. The Power and Transport Services pose the highest challenges to Nigeria's economic growth due to low electricity generation and poor road network. Nigeria, with a population of over 170 million, generates about 6,500 MW of electricity, compared with South Africa's 45,645 MW for a population of 54 million, according to energy experts. Resolving the woes of Nigeria's power and transport sectors is key to attracting foreign direct investments with multiplier effects and economies of scales on other sectors of the economy.

Traditionally, infrastructure investment is often seen in Nigeria as a public good that should be financed by the government. The first time an economic plan was charted for the country was in 1964, when a 10-year Development and Welfare Plan was initiated by the British colonial rule. Afterwards, successive National Development and Rolling Plans were executed spanning 1962 and 1985, and using capital expenditures (CAPEX) from past budgets, and with mixed results. Overall, the implementation of past development plans have created many industries and infrastructure.

\footnotetext{
${ }^{2}$ There appears to be no consensus in the literature on the precise meaning of public-private partnership (or P3s). It has been defined as "a legally-binding contract between government and business for the provision of assets and the delivery of services that allocates responsibilities and business risks among the various partners" (Alitheia, 2010). In a P3s arrangement, government remains actively involved throughout the project's life cycle. The private sector is responsible for the more commercial functions such as project design, construction, finance and operations. P3s involves a contract between a public-sector authority and a private party, in which the private party provides a public service or project and assumes substantial financial, technical and operational risk in the project (Harris, 2003). In some types of P3s, the cost of using the service is borne exclusively by the users of the service and not by the taxpayer. In other types (notably the private finance initiative), capital investment is made by the private sector on the strength of a contract with government to provide agreed services and the cost of providing the service is borne wholly or in part by the government (Scottish Parliament, 2001).
} 
Unfortunately, poor maintenance of existing infrastructural facilities has impacted negatively on the nation's socioeconomic development.

Of late, federal government finance have become grossly inadequate to provide basic infrastructure for Nigeria's rapidly growing population with average growth rate of 2.8 percent per annum, according to the latest data from the National Population Commission of Nigeria (NPC, 2015). The high cost of doing business in the country and inflated contracts have choked government expenditures as well as budget performance overtime. And despite the magnitude of capital expenditures allocated to infrastructure in recent decades, the country has not witnessed appreciable economic growth.

In 1981, Nigeria spent N6.57billion or 7\% of GDP on capital expenditures relative to the N24.05billion or 5\% of GDP expended in 1990. Eighteen years after, specifically from 1991 to 2009, the nation's CAPEX had peaked at N1.15trillion, an astronomical increase of $4014 \%$. Within the period, Nigeria's population also grew by about $57 \%$, from about 98 million to 154 million. However, the sustained growth in the nation's capital votes raising the question of whether the country is getting premium value for every Naira spent (BGL Group, 2015).

The enactment of the Infrastructure Concession Regulatory Act (ICRC) in November 2005 paved way for sustainable public-private sector partnership in infrastructure provision in the country. The rationale is simple; government is increasingly becoming inefficient in allocating resources especially for the provision of critical infrastructure. As a result, private sector's funding and participation was identified as key to tackling Nigeria's infrastructural challenges for economic growth and development (Gunu \& Tsado, 2012).

In a typical PPP model, a private-sector consortium forms a special company called a "special purpose vehicle" (SPV) to develop, build, maintain and operate the asset for the contracted period. In cases where the government has invested in the project, it is typically (but not always) allotted an equity share in the SPV (Grant, 2006). The consortium is usually made up of a building contractor, a maintenance company and bank lender(s). It is the SPV that signs the contract with the government and with subcontractors to build the facility and then maintain it. In the infrastructure sector, complex arrangements and contracts that guarantee and secure the cash flows and make P3s projects prime candidates for project financing. A typical P3s example would be a hospital building financed and constructed by a private developer and then leased to the hospital authority. The private developer then acts as landlord, providing housekeeping and other non-medical services while the hospital itself provides medical services.

Modern P3s is believed to have begun in Britain in 1992 when the Conservative government of John Major introduced the Private Finance Initiative (PFI) which became the first systematic programme aimed at encouraging public-private partnerships (Harris, 2003). This innovative programme focused on reducing the Public Sector Borrowing Requirement. The Labour government of Tony Blair, elected in 1997, continued with the PFI but sought to shift the emphasis to the achievement of "value for money," mainly through an appropriate allocation of risk. Since then, P3s have been used to develop large electric power projects, transportation infrastructure networks including roads, railways, transit systems, seaports and airports. They have also been used in the water, wastewater and gas sectors, as well as for asset-based projects in health care, education, coastal facilities and defense. Examples of such projects abound in the United Kingdom, Australia, Ireland, the province of British Colombia, Canada, India, USA and countries of Latin America and Caribbean (Fulmer, 2009; Alitheia, 2010).

\section{Overview on Nigeria's Pension Funds Assets}

The enactment of Pension Ordinance in 1951 signaled the official commencement of pension payment to employees in Nigeria. But the failure of the scheme to deliver retirement benefits to pensioners as at when due led to a landmark reform in 2004. The Pension Reform Act of 2004 (Pension Act, 2004) established Nigeria's Contributory Pension Scheme for payment of retirement benefits for employees. This was replaced by the Pension Reform Act of 2014 (Pension Act, 2014) which makes provision for the uniform contributory pension scheme for public and private sectors in Nigeria and other related matters. Under the Act, a Retirement Saving Account (RSA) must be opened by employers with Pension Fund Administrators (PFAs) of their choice.

Prior to the Pension Reform Act 2004, the public sector operated Defined Benefit (DB) Scheme that was: largely unfunded or underfunded marred by weak, inefficient and less transparent administration unsustainable due to accumulated pension debt. Private Sector was characterized by low coverage and compliance leaving most workers with no and/or inadequate retirement benefit arrangement

The Pension Reform Act 2004 introduced the Contributory Pension Scheme (CPS) to: provide sustainable, predictable and adequate source of retirement benefits applies to employees in the Public Service of the Federation, the FCT and the Private Sector organizations with 5 or more employees.

The Pension Reform Act 2004 also established the National Pension Commission (PenCom) as the sole regulator and supervisor of pensions matters in Nigeria. 


\subsection{Objectives of the Pension Reform}

a) Ensure that every worker receives his benefits as and when due

b) Empower the worker

c) Assist workers to save in order to cater for their livelihood during old age

d) Stem the growth of outstanding pension liability

e) Establish uniform rules, regulations and standards for administration of pension matters

f) Establish strong regulatory \& supervisory framework

\subsection{Coverage of the Contributory Pension Scheme}

The Contributory Pension Scheme (CPS) coverage by virtue of S. 1 of the PRA (2004) are the followings:
a) Public Service of the Federation
b) Public Service of the FCT
c) Private Sector Organization with 5 or more employees
d) States and LGs that have enacted Laws and adopted the CPS

3.3 Exemption from the Contributory Pension Scheme by Virtue of S. 8 of the PRA
a) Pensioners existing before PRA 2004
b) Persons who had 3 or less years to retire as at June 2004
c) Judicial Officers by virtue of S. 291 of the 1999 Constitution
d) Personnel of the Military, Intelligence and Security Services (PRA Amendment Act 2011)

\subsection{Features of the Contributory Pension Scheme}
a) Contributory and fully funded
b) Shared Responsibility between the employer \& employee
c) Minimum of $15 \%$ of monthly emolument
d) Incremental accumulation of pension funds and assets
e) Based on Individual Retirement Savings Account (RSA)
f) Portable Accounts
g) Employee maintains his RSA for life regardless of transfer of service or change of employment
h) Assets privately managed by PFAs and kept by PFCs
i) Life Insurance Policy maintained by Employer up to three time Annual Total Emolument

\subsection{Modalities and Requirements for Investing Pension Funds}

The Pension Fund Act (2004) and the Regulations provide the modalities, requirements and thresholds for such investments.

Section 86 of the PFA expressly provides for the modes of investment of pension funds subject to the provisions of the guidelines prescribed by the National Pension Commission ("PENCOM"). The modes include but are not limited to Federal government bonds, bills and other securities, state and local Government bonds, bills and other securities, banks deposits and bank securities and real estate developments.

Whilst the PFA makes no express reference to any instrument for investment in infrastructure projects such as roads telecommunications and or power, reference is made to "specialist investment funds and other financial instruments as the Commission may, from time to time approve."

In addition to the PFA, the Regulations also provide guidelines for the investment of pension funds. The Regulation is more definitive on the form of investment for pension funds infrastructure projects. The Regulations define "Specialist Investment Funds" as infrastructure and Private equity registered by the Securities and Exchange Commission ("SEC").3

The Regulations prescribe two main routes through which pension funds asset can be invested in infrastructure projects - eligible bonds or debt instruments and infrastructure funds. Section 3.5(c) of the Regulations and Section 5.2.3 of the Regulations

It should be noted that a draft set of regulations on investment of pension funds has been circulated but yet to be adopted by PENCOM. Once adopted, there will be some slight modifications to the requirements for the investment of 
pension funds through bonds and infrastructure funds in infrastructure projects. The modifications are as follows:

a) The requirement that the infrastructure funds have a satisfactory pre-defined liquidity /exit routes, has been extended by the draft regulations. The draft regulation accepts Initial Public Offer, Sale to other Private Equity Funds and sale to a strategic Investor as satisfactory exit routes for investors.

b) The threshold percentage of infrastructure fund to be invested in projects in Nigeria is reduced from $75 \%$ in the current regulations to $60 \%$ under the draft regulations.

c) Presently, only $5 \%$ of the total pension fund assets can be invested in infrastructure funds and these assets are also held in a single fund.

However, under the proposed draft regulations, a multi-fund structure is established. The multi-fund structure categorizes assets into four tranches based on the overall exposure to variable income instruments. The age of the contributor, work status and the risk exposure elements are also considered in determining which of the tranches the pension funds' assets will be invested in. The tranches are as follows:

a) Fund 1 -suitable for contributors who want to invest in high risk projects with higher rewards;

b) Fund 2 -suitable for contributors aged 49 and below;

c) Fund 3 -suitable for contributors aged 50 and above; and Fund 4 -strictly for RSA retirees.

Under the multi-tiered system, a PFA is also allowed to invest a maximum of 5\% of the pension fund assets in Fund 1 and Fund 2 while the draft regulations stipulates $0 \%$ for Fund 3 and Fund 4.

From the foregoing, it clear that there exists a robust legal and regulatory framework in place for the investment of pension funds in infrastructure projects. However, there appears to be reluctance by the PFAs to invest in the much needed infrastructure projects that are likely to yield significant profits. The factors inhibiting the growth of investment of pension funds in infrastructural projects in Nigeria are multi-faceted. While there are factors arising from the lapses in the legal framework and operational environment; there are also other social, economic and political factors that could have impeded the growth of pension funds investment in infrastructure projects in Nigeria.

The reluctance of the PFAs to invest in infrastructure projects may therefore be attributed to the following factors such as:

a) Bias in the allocation of pension fund assets

b) The regulatory framework expressly allows for the investment of pension funds in infrastructure. However, there is huge bias in the allocation of pension funds' assets allowable for investment in infrastructure.

c) The regulatory framework limits the proportion of pension funds that could be invested in infrastructures to a maximum of $5 \%$ of the total pension funds' assets; compared to other investment allocation, where pension funds can invest up to 80\% in Federal government bonds and 35\% in Money Market instruments.

d) Transparency in the Competitive Bidding Process

The Regulations require that for pension fund assets to be invested in infrastructure projects, such project must be awarded to a concessionaire with a good track record; and must be through an open and transparent bidding process conducted in accordance with the requirements of the Infrastructure Concession and Regulatory Commission Act ("ICRC Act").

Section 4 of the ICRC Act requires that where any project or contract or maintenance of any infrastructure has been approved, the Federal Government Ministry, Agency, Corporation or body concerned shall publish in at least three national newspapers having wide circulation in Nigeria or such other means to invite open competitive bids for such project or contract. The requirement to publish approved project or contract is limited to three national newspapers in Nigeria. Publication in International newspapers or other international media that could attract foreign prospective concessionaires to participate in the competitive bidding process is not considered.

The ICRC Act sadly, is riddled with loopholes which could significantly impact pension funds invested in infrastructure projects. The loopholes are as follows:

a) Section 11 of the ICRC Act stipulates that an agreement made pursuant to the ICRC Act shall not be arbitrarily suspended, stopped, or cancelled except as provided for in the ICRC Act. However, the ICRC Act does not expressly make provisions for the payment of compensation to the concessionaires in the event that the contract is suspended, stopped or cancelled except as may be provided for in the concession agreement. A case in point is the Lagos-Ibadan expressway concession which was suspended and /or cancelled. If a PFA had invested in such venture, it would be in difficulty in recouping its investment.

b) The ICRC Act does not make provisions for the protection of the concessionaires in the events of any change in regulatory framework or polices which might adversely affect the concessionaires. 
c) The ICRC Act does not make provisions for the event of substitution of concessionaires.

d) There is also no clear provision on confirmation by the government to abide by the governing law and dispute resolution mechanisms adopted

e) Though the loopholes can be addressed in concession agreements; there would be greater investor confidence if they were addressed in a statute.

f) Lack of knowledge of the infrastructure sector. An in-depth knowledge of the infrastructure sector is critical to pension fund investment in any country. According to the OECD Survey (2011), "infrastructure investment involves a steep learning curve given the unique nature of each investment."

g) Most of the PFAs in Nigeria, do not have a deep understanding of the infrastructure sector to conduct comprehensive due diligence and perform risk assessments. This major challenge has constrained investors in making an informed decision as to whether or not to invest in infrastructure sector in Nigeria.

h) Shortage of data. The PFAs stands in a fiduciary relationship to fund owners. This relationship requires the PFAs to safeguard the security of the funds under their management. In carrying out this duty, adequate information, historical facts and figures are required for proper assessment of the various risks involved in infrastructure transactions. Unfortunately, in Nigeria, the PFAs do not have adequate data to conduct due diligence and access the various risks involved in infrastructure transactions. This has slowed down the active participation of pension funds in infrastructure.

\subsection{Key Institutions under the Pension Act 2004}

There are key institutions established under the Pension Act (2004) to midwife and regulate the operations of pension funds in Nigeria. They include:

a) The National Pension Commission (PenCom)

The National Pension Commission (PenCom) is the sole regulator and supervisor of the pension industry in Nigeria with mandate to:

i) Regulate and supervise pension schemes

ii) Formulate, direct and oversee the overall policy on pension matters in Nigeria

iii) Approve, license and supervise PFA, PFC and other institutions relating to pension matters

iv) Issue Regulations and Guidelines

v) Maintain National Data Bank on pension matters

vi) Receive and investigate complaints against PFC, PFA and Employer

vii) Enforce sanctions and penalties

b) Pension Fund Administrators (PFAs)

The Pension Fund Administrators are registered operators of the scheme. Among other functions, the PFAs are expected to:

i) Opens RSAs for all employees in liaison with PenCom

ii) Appoints a PFC for receipt of contributions and safe custody of pension funds and assets

iii) Investment of pension funds and assets

iv) Administers retirement benefits to retirees

v) Provides customer support services including account statement

c) Pension Fund Custodians (PFCs)

The Pension Fund Custodians (PFCs) have the responsibility to:

i) Receives pension contributions and informs PFA within 24 hours

ii) Holds pension assets in safe custody in trust for RSA holders and beneficiaries

iii) Executes transactions and other related activities on behalf of the PFA

iv) Closed Pension Fund Custodians (CPFAs)

v) Reserved for private sector employers that were managing their pension before PRA 2004

vi) Approved Existing Private Sector Schemes (AESs)

Over the years, Nigeria has experienced exponential growth in the size of its pension funds. In September 2016, 
Nigeria's pension assets hit N5.9trillion (as shown in Table 1), up from about N2trillion achieved in 2010, representing a 190 percent increase. A breakdown of the utilization of the pension funds reveals that 15 percent of the assets constitute bonds' investment, 5 percent invested in infrastructure funds, 35 percent in corporate bonds' investment, 20 percent in mutual funds and the remaining 25 percent is regarded as other assets, according to the National Pension Commission (PENCOM, 2016)

On the flip side, Nigeria's ailing infrastructure is among the worst globally, crippling trade and investment and causing untold hardships to Nigerians. Consequently, industry experts have called for an investment of parts of the pension assets in bridging the country's infrastructural gap estimated at N2.9trillion dollars. According to industry analysts, Nigeria would need to invest an estimated $\$ 50$ billion annually over the next fifty years on infrastructure development to achieve inclusive growth, enhance per capita income and improve standard of living.

\section{Leveraging Pension Funds for Infrastructural Development}

To effectively utilize the pension funds for infrastructure development and economic growth, it is important to review the extant provisions of Nigeria's pension law. According to Nigeria's Pension Act 2014, the Pension Fund Administrators (PFAs) are saddled with the responsibility of investing pension funds with the overall objective of safety and maintenance of fair returns on amount invested. However, the investment of the pension assets shall be subject to regulations and guidelines issued by the National Pension Commission (PenCom), from time to time. According to the guidelines issued by PenCom in 2015, Pension funds shall be invested in the following assets category:

1. Bonds, Sukuk, Bills and other securities issued by the Central Bank of Nigeria, local government, state or federal government.

2. Bonds, Sukuk, Ordinary Shares, Debentures, Redeemable preference shares and other debt instruments issued by a corporate entity listed on the Nigerian Stock Exchange.

3. Supranational bonds and Sukuk issued by a multilateral development finance organizations.

4. Money markets instruments or banks and Commercial Papers issued by corporate entities.

5. Investment certificates listed on securities exchange and registered under Investment and Securities Act (ISA)

6. Global Depositary Receipts/Notes, Eurobonds and Sukuk issued by listed Nigerian companies.

7. Specialist investment funds including real estate development investments, as PenCom may sanction from time to time.

8. Investment in Nigeria's pension assets abroad, among others.

In view of the foregoing, leveraging on Nigeria's pension assets for infrastructural development requires a deep and sustained partnership between the federal and state government on one hand, and the National Pension Commission and the Pension Fund Administrators on the other hand.

And in line with the provision of the new pension Act, the federal government may float infrastructure bonds that could attract PFAs' subscription, subject to the approval of PenCom from time to time. The Commission now seeks to invest about 40 percent of the country's pension funds in infrastructure and housing by 2019. To harness this opportunity, the federal government of Nigeria has mapped out strategies to float \$25billion infrastructure fund. This will likely facilitate the upgrading of the country's ailing infrastructure and provide investment opportunities for new ones.

Besides, a long term perspective and equal matching of infrastructural projects with pension funds, will pave way for the adoption of pension assets as a means of financing Nigeria's infrastructure gap. And given adequate guarantee of pension funds, investors and retirees could enjoy higher returns over a long time. It may also provide safety nets for the investment of pension assets under the special investment funds and other financial instruments, as stipulated by the investment guidelines of the pension Act. Nonetheless, sound policy frameworks and modalities for a secure pension assets' investment should be put in place by the federal government. This will encourage PFAs, PenCom, pensioners and other stakeholders to support the scheme. Clear guidelines for the selection process of key infrastructural projects will be of great interest to investors. This may likely include the project's expected cash flows, payback periods and return on investments. And if the federal government could introduce tax incentives and rebates, the PFAs will be incentivized to invest.

Essentially, foreign investors will be keen to see how the federal government will convince over 7.2 million pension contributors and 170,000 retirees, to perceive infrastructural financing as a safe haven to invest their pension assets on.

In a bid to encourage investment of pension assets, the Central Bank of Nigeria (CBN) has proposed various initiatives for leveraging pension funds for infrastructural development. Nigeria Infrastructure Guarantee Scheme (NIGS) is one of such initiatives aimed at providing reasonable assurance for the financial instruments that will be likely used for infrastructure projects. The scheme will also provide at least 80 percent guarantee for any project approved by the 
Infrastructure Concession Regulatory Commission subject to a maximum of \$1billion. Similarly, the Nigerian Pension Fund Asset Guarantee Scheme (NPFAGS) will secure the portion of pension funds used for infrastructural development. NPFAGS' operational modality will also follow a similar trajectory as NIGS, according to the CBN (2015). Another proposal that could secure pension assets is Nigerian Infrastructure Project Revenue Guarantee Scheme (NIPRGS). This will likely provide guarantee for the expected cash inflows from any project executed. It is instructive to note that these guarantees could be financed by the Nigeria Infrastructure Fund (NIF). Another initiative worth mentioning here is the Special Purpose Entity (such as Build Nigeria Infrastructure Bond) that will be responsible for raising infrastructure bonds from the pension assets. This will be guaranteed by the Central Bank of Nigeria (CBN) and some income generating assets of the government. Finally, putting in place an effective legal and regulatory framework to guide the entire process would be imperative in ensuring the continuity of public projects financed by pension assets.

Overall, the aforementioned initiatives must conform to the stipulated PenCom's guidelines, to have any bite.

\subsection{Other Countries Case Studies}

Globally, countries use pension assets to finance infrastructural development (Alonso et al., 2010; Beeferman, 2013). The proportion of pension funds used for economic growth in Canada, Australia, and the United States of America are 5 percent, 10 percent, and 3 percent respectively, according to industry analysts (Vives, 2000; Alonso et al., 2010). For instance, Canada's biggest pension funds is worth over C\$1.1trillion as at June, 2016 (Pension Investment Association of Canada (2016). Canadian Funds' managers have also shown keen interest in financing major infrastructural projects in the short to medium term, based on the condition that the federal government of Canada provides adequate guarantees on expected future returns and reasonable assurances on planned expenditures. The targeted sectors will include public transport, affordable housing, and renewable energy, among others. For instance, Caisse, Canada's second largest pension fund, invested about $\$ 10.3$ billion in Australia's TransGrid electricity network (Pension Investment Association of Canada (2016).

Recently, in the United States, the largest pension funds, the California Public Employees Retirement Scheme, invested \$155million in London Gatwick Airport, representing a 12.7 percent stake (Della-Croce, Schieb \& Stevens, 2011). Investment experts forecast showed that global pension manages in the United States will invest more than US\$3.5trillion in traditional and social infrastructure within the next decades (Berwin Leigthon Paisner (BLP), (2010). Similarly, Australia retirement funds invests about 5 percent of its pension assets in infrastructure, accounting for over $\$ 80$ billion of its pension funds, according to the Organization for Economic Corporation and Development (OECD). Nigeria could also leverage on both local and global pension assets to finance its fiscal deficits especially for infrastructure development.

\subsection{Opportunities}

1. Infrastructure development through deployment of pension assets may lead to multiplier effects, and ultimately impact positively on Nigeria's economic growth and development. Indeed, thousands of direct and indirect jobs could be created in sectors such as trade and commerce, ICT (especially broadband infrastructure), transport, power, health, education and water supply, among others. According to Inderst (2013), stocks of physical infrastructure could raise a country's gross domestic product (GDP) by an estimated 2 percent in the short run.

2. A successful investment of pension funds in infrastructure will likely bring higher returns on investment, over a long time period. With high degree of transparency and legal frameworks by the federal government, both local and foreign investors would be encouraged to commit stake in Nigeria's infrastructure bonds.

3. Pension assets provide one of the cheapest sources of capital funding to diversify Nigeria's mono-cultural economy. The astronomical growth of pension funds to about N6trillion may cushion the shocks and imbalances resulting from a slump in oil receipts and its attendant stagflation. This will facilitate infrastructural development though Public Private Partnership (PPP).

4. Nigeria could avoid foreign exchange and country risk associated with utilizing external loans for infrastructural developments, by leveraging pension assets for economic growth.

5. Pension fund's investment in infrastructure may permanently address Nigeria's annual budget deficits, especially capital expenditures' estimate. Consequently, resources could be channeled to other competing needs and sectors.

\subsection{Inherent Risks}

1. One of the greatest challenges to the investment of pension funds in infrastructure is the unavailability of qualifying investment instruments in line with the investment guidelines issued by the National Pension 
Commission (PenCom). Pension fund managers, will naturally, be interested in the liquidity and solvency risks associated with infrastructure funding.

2. Also, transparency in competitive bidding process of projects remains elusive, although the ICRC Act requires that an open bidding process should be carried out, however, in practice, project selection criteria in Nigeria is not truly transparent.

3. Besides, paucity of data available to PFAs in appraisal of ICRC approved projects may hinder effective monitoring of key projects. Lack of adequate due diligence and risk analysis on infrastructure transactions may increase the investment apathy of PFAs and PenCom, towards infrastructural financing.

4. Infrastructure Concession and Regulatory Commission Act does not provide for payment of compensation to the concessionaires in the event of cancellation or suspension of infrastructure projects. And with high rate of abandoned projects in Nigeria, there is an urgent need to fix this loophole to encourage investors, especially PFAs and other institutional investors.

5. Ineffective engagement of relevant stakeholders regarding the use of pension assets for infrastructure provision is another issue. These stakeholders include pensioners, labour unions, government, pension fund administrators, pension fund custodians, National Pension Commission, construction companies, among others.

\section{Policy Implication, Conclusion and Recommendations}

About 55 percent of pension contributors in Nigeria are less than 40 years, paving the way for long term investment of pension assets for the provision of critical infrastructure, according to latest data from the National Pension Commission. However, high rate of unemployment due to current economic recession, and the continued depreciation of the Naira could be the biggest threats to pension assets as its dollar value fell sharply by a whopping US\$10billion between 2014 and mid-2016 (Matsukwawa \& Habeck, 2016). This may significantly push up project costs beyond completion, hurting future investments of Nigeria's pension funds in infrastructure projects.

It is clear that despite the legal and socio-cultural factors inhibiting the growth of investment of pension funds in infrastructure in Nigeria, several lessons can be learnt from the Azura project and the experiences of other countries with developed pension markets to create enabling environment for pension funds investment in infrastructure in Nigeria.

To this end, it is recommended that:

a) The government should consider issuing bonds (For example, Build Nigeria Bonds) specifically dedicated to infrastructural projects and duly backed by full government guarantee similar to the one issued in the Azura project; and other technical and financial support to attract pension funds

b) A structure needs to be developed for incentivizing PFAs particularly tax incentives, and rebates to encourage PFAs to invest in infrastructure projects

c) An upward review of the percentage of the total pension funds asset that can be invested in infrastructure should be considered. This will give the PFAs the opportunity to consider investing more in infrastructure

d) The ICRC Act should be reviewed to incorporate provisions that will guarantee transparency in the appointment of a concessionaire with good track record.

e) The Infrastructure Concession Regulatory Commission (ICRC) must be independent in conducting a fair, transparent bidding process in the concessioning and award of infrastructure projects.

f) There is need for increased transparency in the project implementation process and provision of quantitative data to enable pension fund managers conduct due diligence and effectively access the risks involved in investing in infrastructure.

g) The ICRC should review their project data base by including other vital information that would enable PFAs make an informed decision on investment in infrastructure projects.

h) There has to be more active engagement of the government with all stakeholders involved in infrastructural development in the country to generate ideas towards active involvements of pension funds in infrastructure.

\section{References}

Akinyosoye. (2010). Strategic Risk Management: Comparative Study on its impact of successful implementation of Public-Private Partnership Projects in Africa. MSc Thesis, University of Bath, Bath, UK.

Alitheia, C. (2010), Public Private Partnerships (PPPs) - The Effective Mechanism for Delivering Infrastructure. Available at www. Thealitheia .com /newsletters /Alitheia \%20Capital\% (accessed 9 September 2017). 
Alonso, J., Bjeletic, J., Herrera, C., Hormazábal, S., Ordóñez, I., Romero, C., \& Tuesta, D. (2010). A balance of Pension Funds Infrastructure Investments: The Experience in Latin America, Economic Research Department Number $10 / 03$

Aremu, K. (2016). Leveraging Pension Assets to Bridge Infrastructural Gap. Zenith Economic Quarterly, 12(4), 35-42

Beeferman, L. W. (2008). Pension Fund Investment in Infrastructure: A Resource Paper, Labor and Work life Program, Harvard Law School, 125 Mt. Auburn St., 3rd Floor, Cambridge, MA 02138.

Berwin Leigthon Paisner (BLP). (2010). Driving Growth - Building Block for global Infrastructure. London, UK.

BGL Group. (2016). BGL Pension Report - Situating Nigeria in the Global Pension Industry. Lagos, Nigeria.

Della, C. R., Kaminker, C., \& Stewart, F. (2011). The Role of Pension Funds in Financing Green Growth Initiatives, OECD Working Papers on Finance, Insurance and Private Pensions, No. 10, OECD Publishing, Paris.

Foster, V., \& Pushak, N. (2011). Nigeria's Infrastructure - A continental Perspective. World Bank Policy paper 5686. World Bank, Washington D.C., USA. https://doi.org/10.1596/1813-9450-5686

Fulmer, J. (2009). What in the world is infrastructure? PEI Infrastructure Investor (July/August), 30-32.

Grant, T. (1996). Keys to successful public-private partnerships. Canadian Business Review, 23(3), 27-8.

Gunu, U., \& Tsado, E. (2012). Contributory Pension System as a Tool for Economic Growth in Nigeria, international. Journal of Business and Behavioral Sciences, 2(8), 6-13.

Harris, S. (2003). Public private partnerships: delivering better infrastructure services, A Working Paper Presented at the Workshop Organized by Inter-American Development Bank in Washington, DC, available at: www.pppcentrum.cz/res/data/001/000167.pdf (accessed $7^{\text {th }}$ September, 2017).

Inderst, G. (2013). Pension Fund Investment in Infrastructure, OECD Working Papers on Insurance and Private Pension No 32. Paris, France.

Matsukwawa, T., \& Habeck, O. (2016). Recent Trends in Risk Mitigation Instruments for Infrastructure Finance. Public Private Infrastructure Advisory Facility (PPIAF). World Bank. Washington D.C., USA

National Infrastructure Integrated Master Plan. (2013). Federal Government of Nigeria, Government Press, Abuja.

National Pension Commission. (2010). Regulation on Investment of Pension Fund Assets [online]. Available from \{www.pencom.gov.ng\}. [Accessed September 6, 2017]

National Pension Commission (Pencom). Monthly, Quarterly and Annual report and Annual Accounts (2007 - 2016). http://www.pencom.gov.ng

National Pension Commission. (2015). 2015 Annual Report \& Statement of Accounts [online]. Available from \{www.pencom.gov.ng\}. [Accessed September 6, 2017]

Nigeria Pension Reform Act No 2. (2004). Federal Government of Nigeria. Abuja, Nigeria.

Nigeria's Pension Reform Act No 2 of. (2004). Federal Government of Nigeria, Government Press, Abuja.

Nigerian Economic Summit Group (NESG). (2012). Harnessing Pension Funds for Sustainable Development, NESG Position Paper, February 2012, NESG, Lagos, Nigeria

Pension Investment Association of Canada. (2016). Accessed on $7^{\text {th }}$ September, 2017 at http://www.piacweb.org/publications/index.html

Scottish Parliament. (2001). Public-Private Partnerships and the Private Finance Initiative: A Review of Recent Literature. Edinburgh: Scottish Parliament Information Centre.

Vives, A. (2000). Pension Funds in Infrastructure Project Finance - Regulations and Instrument Design. Inter-American Development Bank, Washington D.C., USA.

\section{Copyrights}

Copyright for this article is retained by the author(s). with first publication rights granted to the journal.

This is an open-access article distributed under the terms and conditions of the Creative Commons Attribution license which permits unrestricted use, distribution, and reproduction in any medium, provided the original work is properly cited. 